\title{
Evaluation of the microbiological quality of ricotta cheese commercialized in Santa Catarina, Brazil
}

\author{
Edailson Luís Xavier GUATEMIMํㅗㄴ Sheila Mello da SILVEIRA², Alessandra Farias MILLEZI², \\ Mariane FERENZ ${ }^{2}$, Karine Dalla COSTA ${ }^{2}$, Paula ROSSI ${ }^{1}$, Gabriel Bonetto BAMPI ${ }^{1 \star}$
}

\begin{abstract}
Ricotta cheese has low fat and salt contents and a high quantity of proteins. The diversity of the nutrients and the high water content are factors that favor the development of microorganisms in this product. In this context, the aim of this study was to evaluate the microbiological quality of ricotta commercialized in the western region of Santa Catarina State, Brazil. Thirty samples, comprising 10 different brands of ricotta, were collected and sent to the Food Microbiology Laboratory at the Instituto Federal Catarinense (IFC), Campus Concórdia for microbiological analysis to determine the presence of Salmonella sp., Listeria sp., coagulase-positive Staphylococcus and thermotolerant coliforms. Of the 30 samples, the results for $33.3 \%$ were not within the parameters established by current legislation, that is, they were not fit for human consumption. This high percentage was due to contamination by thermotolerant coliforms, with 10 samples containing this group of microorganisms. One sample was contaminated with Listeria grayi, and for the other microorganisms investigated, (Salmonella sp. and coagulase-positive Staphylococcus) the results were satisfactory. This study characterizes the hygiene-sanitary conditions of ricotta commercialized in the western region of Santa Catarina State, highlighting the need for greater care during the production of this product.
\end{abstract}

Keywords: Salmonella sp.; Listeria sp.; coagulase-positive Staphylococcus; thermotolerant coliforms; Listeria grayi.

Practical Application: The consumption of cheese is increased significantly in Brazil. A cheese that stands out is the ricotta by a high percentage of nutrients and high water activity, however, this excellent composition favors the development of microorganisms. Thus, microbiological analysis have a great importance to evaluate the product. The results allow to characterize the hygiene-sanitary conditions ricotta cheese suggesting expansion of quality controls in the industry.

\section{Introduction}

The consumption of cheese in Brazil is increasing every year. The Brazilian Association of Cheese Producers (ABIQ) estimates that the national cheese companies, which undergo federal inspection (SIF), produced 1,100,000 tons of cheese in 2014 , industrializing approximately 11 billion liters of milk per year. This represents a 7\% increase compared to 2013 (Scarcelli, 2015).

Several studies show the use of cheese as a functional food. Cheeses, in addition to probiotic cultures, are considered as an alternative to diversify the market presenting itself as a potentially useful food to improve the health of consumers. We can highlight the benefits: the attenuation of hypertension, meaningful decrease of LDL cholesterol and the triglycerides levels, as well as the increases of HDL cholesterol (Lollo et al., 2015; Dantas et al., 2016).

Ricotta is a cheese that is noted for its high quantity of proteins, low fat and salt content and other important components, which give this product a high nutritional value. It is consumed all over the world in many diets (Ribeiro et al., 2005; Silva et al., 2012).
Ricotta is considered to be of Italian origin, and it is known as an albumin cheese due to the presence of protein in its composition together with lactoglobulin. These proteins are not coagulated by curdling and are easily denatured and precipitated by heat when acidified. The production yield is approximately 4 to $6 \%$. It is considered a fresh cheese and has a short shelf life (Furtado, 1994; Ribeiro et al., 2005).

Fresh ricotta is a product of animal origin that presents good conditions for the development of microorganisms, mainly due to the availability of nutrients, which reduces the shelf life of the product. Another factor that makes ricotta susceptible to microbiological contamination is high water activity. Thus, microbiological analysis is important to monitor the shelf life and also to evaluate food safety because food products that are not in good sanitary condition should not be consumed (Maia et al., 2004; Franco \& Landgraf, 2008; Moura et al., 2013).

In varied microbiological analysis conducted in researches, it was possible to perceive the presence of pathogens in cheese or in environments of dairy industries (Carrijo et al., 2011; Cereser et al., 2011; Barancelli et al., 2014) what justifies the 
need of studies related to the microbiological evaluation of these products.

In this context, the aim of this study was to verify the microbiological quality of ricotta cheese sold in supermarkets in the western region of Santa Catarina State, Brazil.

\section{Materials and methods}

To carry out this study, 30 samples of ricotta covering convenience sampling 10 different brands were collected from supermarkets in the western region of Santa Catarina State, Brazil, during the period of March to July 2014, taking note of the lot and expiration date (Carrillo et al., 2012; Felicio et al., 2013).

The samples were analyzed at the Food Microbiology Laboratory at the Instituto Federal Catarinense (IFC), Campus Concórdia according to the Brazilian standard Instrução Normativa $\mathrm{n}^{\circ} 62$ (Brasil, 2003) because the values therein are recognized by the current legislation RDC no 12 (Agência Nacional de Vigilância Sanitária, 2001). The Normative Instruction $n^{\circ} 62$ (Brasil, 2003) establishes the analytical official methods to microbiological analyses to control water and animal origin products. The RDC $\mathrm{n}^{\circ} 12$ (Agência Nacional de Vigilância Sanitária, 2001) establishes the sanitary microbiological patterns to food which is destined to human consumption.

The analysis to determine the presence of Salmonella sp. was carried out using the solid media XLD and BPLS agars. The detection and identification of Listeria sp. were performed following the BAM/FDA method with biochemical identification using the API Listeria system (BIO-Merieux).

To the coagulase-positive Staphylococcus it was used the plating method in agar Baird-Parker surface. And the enumeration of thermotolerant coliforms were carried out by the multiple-tube technique once it inoculated the sample in Laurylsulfate syrup and the presence of coliforms was shown by the formation of tubes of Durhan gas. To further confirmation of the presence of thermotolerant coliforms it was used syrup EC (Brasil, 2003).

The results are expressed as presence/absence for Salmonella sp., identification for Listeria sp., and CFU/g for coagulase-positive
Staphylococcus and MPN/g for thermotolerant coliforms. The statistical analyses were performed using the software XLSTAT 2012.5 for Windows (Adinsoft, Paris, France).

\section{Results and discussion}

The microbiological analysis results for Salmonella sp., Listeria sp., thermotolerant coliforms and coagulase-positive Staphylococcus are shown in Table 1.

Out of the 30 samples analyzed, 10 (33.3\%) were contaminated with thermotolerant coliforms with values above $5.0 \times 10^{2} \mathrm{MPN} / \mathrm{g}$, which is the limit established by legislation (Agência Nacional de Vigilância Sanitária, 2001). In terms of this parameter, the following brands were not approved: C, E, F, G, H and J. Cereser et al. (2011) analyzed ricotta samples in São Paulo and found higher levels of contamination, showing that $83 \%$ were contaminated with thermotolerant coliforms.

Escherichia coli is the main representative of the thermotolerant coliforms. The environment most appropriate for the development of these bacteria is the intestinal tract of warm-blooded animals. However, they can also be introduced into food products from non-fecal sources. The contamination of milk and its derivatives by thermotolerant coliforms can indicate failures during the processing or contamination after the pasteurization of milk because these microorganisms are easily destroyed by heat; thus, they should not be present after heat treatment. They can also be related to hygiene failures during the production process because coliforms are easily destroyed with the proper use of sanitizers (Silva et al., 2010; Kormann, 2011; Silva \& Fortuna, 2013).

In dairy products industries, the pathogens are generally existent in contaminated raw milk, since they may colonize the environment as well as equipments and, posteriorly contaminate the dairy products. Thus, hygiene in industries may be regarded as well as disinfection programs must be implanted (Kousta et al., 2010).

Milk and its derivatives, in particular fresh cheeses, have been associated with outbreaks of listeriosis in several countries in recent years. Listeriosis is caused by Listeria monocytogenes. Industrially, the main routes of contamination of a final product

Table 1. Average results obtained in the microbiological analysis of ricotta cheese.

\begin{tabular}{|c|c|c|c|c|}
\hline Ricotta Brands & Thermotolerant coliforms & Listeria sp. & Salmonella sp. & $\begin{array}{c}\text { Coagulase-positive } \\
\text { Staphylococcus }\end{array}$ \\
\hline $\mathrm{A}$ & $<3 \mathrm{MPN} / \mathrm{g}$ & Listeria grayi $(99.8 \%)^{(1)}$ & Absent & $<100 \mathrm{CFU} / \mathrm{g}$ \\
\hline B & $>1100 \mathrm{MPN} / \mathrm{g}^{(2)}$ & Absent & Absent & $<100 \mathrm{CFU} / \mathrm{g}$ \\
\hline $\mathrm{C}$ & $1100 \mathrm{MPN} / \mathrm{g}^{(1)}$ & Absent & Absent & $<100 \mathrm{CFU} / \mathrm{g}$ \\
\hline $\mathrm{D}$ & $3 \mathrm{MPN} / \mathrm{g}$ & Absent & Absent & $<100 \mathrm{CFU} / \mathrm{g}$ \\
\hline $\mathbf{E}$ & $>1100 \mathrm{MPN} / \mathrm{g}^{(2)}$ & Absent & Absent & $<100 \mathrm{CFU} / \mathrm{g}$ \\
\hline $\mathbf{F}$ & $>1100 \mathrm{MPN} / \mathrm{g}^{(1)}$ & Absent & Absent & $<100 \mathrm{CFU} / \mathrm{g}$ \\
\hline G & $>1100 \mathrm{MPN} / \mathrm{g}^{(1)}$ & Absent & Absent & $<100 \mathrm{CFU} / \mathrm{g}$ \\
\hline $\mathbf{H}$ & $>1100 \mathrm{MPN} / \mathrm{g}^{(2)}$ & Absent & Absent & $<100 \mathrm{CFU} / \mathrm{g}$ \\
\hline I & $<3 \mathrm{MPN} / \mathrm{g}$ & Absent & Absent & $<100 \mathrm{CFU} / \mathrm{g}$ \\
\hline J & $>1100 \mathrm{MPN} / \mathrm{g}^{(1)}$ & Absent & Absent & $<100 \mathrm{CFU} / \mathrm{g}$ \\
\hline
\end{tabular}

MPN/g = Most Probable Number per gram; CFU/g = Colony Forming Unit per gram. Number of samples above the limit established by current legislation: ${ }^{(1)}=$ one sample above the limit. ${ }^{(2)}=$ two samples above the limit. Thermotolerant coliforms - maximum limit analyzed of $1100 \mathrm{MPN}$, higher values indicated by $>1100 \mathrm{MPN}$ according to current legislation.

Source: The author (2014). 
by this microorganism are through the environment and the inadequate pasteurization of milk (Borges et al., 2009).

According to Brazilian legislation (Agência Nacional de Vigilância Sanitária, 2001), L. monocytogenes must be absent from the products. Of the ricotta samples analyzed, one (brand A) showed contamination by Listeria grayi. According to Tompkin (2002), there is a need for a response to the presence of any species of Listeria with the same degree of care applied in the determination of $L$. monocytogenes through effective hygienization procedures during processing to ensure efficient control of these microorganisms; however, the legislation establishes criteria only for L. monocytogenes.

With regard to Salmonella sp., the ricotta samples evaluated in this study provided satisfactory results, that is, they were free of this microorganism. The results obtained by Cereser et al. (2011) and Esper et al. (2011) are in agreement with those reported herein because no samples gave positive Salmonella sp. results.

The ricotta samples analyzed were compliant with the legislation in relation to coagulase-positive Staphylococcus. Esper et al. (2011) evaluated ricotta samples and only $2.2 \%$ showed coagulase-positive Staphylococcus counts above $5.0 \times 10^{2} \mathrm{CFU} / \mathrm{g}$, which is the value established by RDC $\mathrm{n}^{\circ} 12$. In a study carried out by Cereser et al. (2011), 18.3\% of the ricotta samples analyzed were not fit for human consumption because they showed excessive contamination by coagulase-positive Staphylococcus.

According to Kousta et al. (2010) the main way to raw milk contamination with Staphylococcus aureus is through infections in cows by mastitis, once the asymptomatic infection is the one which concerns the most but the clinical mastitis also attacks cows causing severe economical loss.

Of the 30 ricotta samples analyzed in this study, 36.7\% were in an unsatisfactory sanitary condition (presence of thermotolerant coliforms and Listeria grayi). In research carried out by Freire et al. (2012), 50\% of the pressed ricotta samples analyzed had an unsatisfactory sanitary quality and thus were unsuitable for human consumption.

Carrijo et al. (2011) analyzed 10 samples of ricotta commercialized in Niterói, Rio de Janeiro State, Brazil, and $100 \%$ did not reach the microbiological standards established by current legislation because the levels of thermotolerant coliforms were above the limits imposed (Agência Nacional de Vigilância Sanitária, 2001). Also, 50\% of the samples were contaminated with coagulase-positive Staphylococcus.

The studies cited above and the results of the research reported herein reveal that a high level of the samples were unfit for human consumption, which can be explained by the fact that this is an artisanal product that requires a high degree of handling. In many cases, good hygiene practices are not in place, allowing for the development of microorganisms that cause food poisoning (Cavalcanti, 2014).

Dias et al. (2012) developed a task which enabled to evaluate the implementation process of Good Manufacturing Practices (GMP) in a processing unit of mozzarella cheese. It was apparent that the implementation of GMP enabled the meaningful decrease of microbiological contamination in equipments and handlers hands. Another observed matter was the reduction of incongruities during the whole process, which evidences that the accomplished research changed the behavior of people, pursuant to, enabling a higher quality cheese production comparing to the ones which were produced before the GMP implementation.

Meaningful decreases in population of microorganisms were observed by Cusato et al. (2013) when evaluated the implementation of a security food system in an industry of dairy processing. This article exhibited that during the implementation process of a security food system great challenges are faced, however the final evaluations enable analyze positively these food industry changes.

The microbiological contamination indexes of ricotta cheese discovered in these works suggest the GMP and Hazard Analysis and Critical Control Points (HACCP) must be embraced by industries with the aim of producing an aliment with greater food security.

\section{Final considerations}

The results obtained for the ricotta samples reveal serious problems associated with contamination. Of the 30 samples evaluated that were obtained from the western region of Santa Catarina State, Brazil, 33.3\% were unfit for human consumption because they were contaminated with thermotolerant coliforms. In addition, one sample (3.3\%) was contaminated with Listeria grayi, which although not covered by the current legislation, can be considered as a health risk in food. This high prevalence of contamination suggests that strict hygiene measures need to be adopted by the producers to obtain a product with satisfactory microbiological quality that is safe in terms of consumer health.

\section{References}

Agência Nacional de Vigilância Sanitária - ANVISA. (2001, January 10). Aprova o regulamento técnico sobre padrões microbiológicos para alimentos (Resolução RDC n 12 , de 2 de janeiro de 2001). Diário Oficial da União.

Barancelli, G. V., Camargo, T. M., Gagliardi, N. G., Porto, E., Souza, R. A., Campioni, F., Falcão, J. P., Hofer, E., Cruz, A. G., \& Oliveira, C. A. F. (2014). Pulsed-Field Gel Electrophoresis characterization of Listeria monocytogenes isolates from cheese manufacturing plants in São Paulo, Brazil. International Journal of Food Microbiology, 173(3), 21-29. http://dx.doi.org/10.1016/j.ijfoodmicro.2013.12.018. PMid:24412413.

Borges, M. F., Andrade, A. P. C., Arcuri, E. F., Kabuki, D. Y., \& Kuaye, A. Y. (2009). Listeria monocytogenes em leite e produtos lácteos (Documentos, Vol. 119). Fortaleza: Embrapa Agroindústria Tropical.

Brasil, Ministério da Agricultura Pecuária e Abastecimento - MAPA. (2003, September 18). Métodos analíticos oficiais para análises microbiológica para controle de produtos de origem animal e água (Instrução normativa ${ }^{\circ}$ 62, de 26 de agosto de 2003). Diário Oficial da União, seção 1.

Carrijo, K. F., Cunha, F. L., Neves, M. S., Ferreira, P. N. S., Nunez, E. S. C. L., Franco, R. M., Milhomen, R., \& Nobres, F. S. D. (2011). Avaliação da qualidade microbiológica e físico-química de ricotas frescas comercializadas no município de Niterói, Rio de Janeiro, Brasil. Veterinaria Noticias, 17(2), 97-110. 
Carrillo, E., Varela, P., \& Fiszman, S. (2012). Influence of nutritional knowledge on the use and interpretation of Spanish nutritional food labels. Journal of Food Science, 77(1), H1-H8. http://dx.doi. org/10.1111/j.1750-3841.2011.02479.x. PMid:22132819.

Cavalcanti, F. B. (2014). Avaliação microbiológica do queijo "tipo ricota" comercializados em supermercados de Campina Grande PB (Monograph). Universidade Estadual da Paraíba, Campina Grande.

Cereser, N. D., Rossi, J. O. D., Marchi, P. G. F., Souza, V., Cardozo, M. V., \& Martineli, T. M. (2011). Avaliação da qualidade microbiológica da ricota comercializada em supermercados do estado de São Paulo. Ciência Animal Brasileira, 12(1), 149-155.

Cusato, S., Gameiro, A. H., Corassin, C. H., Sant'Ana, A. S., Cruz, A. G., Faria, J. A. F., \& Oliveira, C. A. F. (2013). Food safety systems in a small dairy factory: implementation, major challenges, and assessment of systems' performances. Foodborne Pathogens and Disease, 10(1), 6-12. http://dx.doi.org/10.1089/fpd.2012.1286. PMid:23153286.

Dantas, A. B., Jesus, V. F., Silva, R., Almada, C. N., Esmerino, E. A., Cappato, L. P., Silva, M. C., Raices, R. S., Cavalcanti, R. N., Carvalho, C. C., Sant'Ana, A. S., Bolini, H. M. A., Freitas, M. Q., \& Cruz, A. G. (2016). Manufacture of probiotic Minas Frescal cheese with Lactobacillus casei Zhang. Journal of Dairy Science, 99(1), 18-30. http://dx.doi.org/10.3168/jds.2015-9880. PMid:26519974.

Dias, M. A. C., Sant'Ana, A., Cruz, A. G., Faria, J. A. F., Oliveira, C. A. F., \& Bona, E. (2012). On the implementation of good manufacturing practices in a small processing unity of mozzarella cheese in Brazil. Food Control, 24(1-2), 199-205. http://dx.doi.org/10.1016/j. foodcont.2011.09.028.

Esper, L. M. R., Kabuki, D. Y., \& Kuaye, A. Y. (2011). Qualidade microbiológica de ricotas comerciais e os riscos associados à presença de Listeria monocytogenes. Revista do Instituto Adolfo Lutz, 70(4), 554-559.

Felicio, T. L., Esmerino, E. A., Cruz, A. G., Nogueira, L. C., Raices, R. S. L., Deliza, R., Bolini, H. M. A., \& Pollonio, M. A. R. (2013). Cheese. What is its contribution to the sodium intake of Brazilians? Appetite, 66(1), 84-88. http://dx.doi.org/10.1016/j.appet.2013.03.002. PMid:23500416.

Franco, B. D. G. M., \& Landgraf, M. (2008). Microbiologia dos alimentos. São Paulo: Atheneu.

Freire, C. A., Munhoz, I. C. L., Dornelas, M. M., Moreira, P. S., Germano, J. L., Mauch, R. M., Carvalho, P. L. N., Avelino, C. C., \& Veiga, S. M. O. M. (2012). Pesquisa de Listeria monocytogenes em ricotas comercializadas no Sul de Minas Gerais. In Seminário de Iniciação Científica da UNIFAL-MG, Alfenas.

Furtado, M. M. (1994). Tecnologia de queijos: manual técnico para produção industrial de queijos. São Paulo: Pipemar.

Kormann, M. M. (2011). Análise microbiológica de queijo tipo "minas frescal", comercializado em feiras livres de Curitiba, PR. Higiene Alimentar, 25(200-201), 75-79.

Kousta, M., Mataragas, M., Skandamis, P., \& Drosinos, E. H. (2010). Prevalence and sources of cheese contamination with pathogens at farm and processing levels. Food Control, 21(6), 805-815. http:// dx.doi.org/10.1016/j.foodcont.2009.11.015.

Lollo, P. C. B., Morato, P. N., Moura, C. S., Almada, C. N., Felicio, T. L., Esmerino, E. A., Barros, M. E., Amaya-Farfan, J., Sant’Ana, A. S., Raices, R. R. S., Silva, M. C., \& Cruz, A. G. (2015). Hypertension parameters are attenuated by the continuous consumption of probiotic Minas cheese. Food Research International, 76(3), 611-617. http:// dx.doi.org/10.1016/j.foodres.2015.07.015.

Maia, S. R., Ferreira, A. C., \& Abreu, L. R. (2004). Uso do açafrão (Curcuma longa L.) na redução da Escherichia coli (ATCC 25922) e Enterobacter aerogenes (ATCC 13048) em ricota. Ciência e Agrotecnologia, 28(2), 358-365. http://dx.doi.org/10.1590/S1413-70542004000200016.

Moura, L. B., Moura, R. L., \& Guimarães, F. R. (2013). Análise de Coliformes e Salmonella em leite pasteurizado no sertão central do Ceará. Higiene Alimentar, 27(216-217), 146-149.

Ribeiro, A. C., Marques, S. C., Sodré, A. F., Abreu, L. R., \& Piccoli, R. H. (2005). Controle microbiológico da vida de prateleira de ricota cremosa. Ciência e Agrotecnologia, 29(1), 113-117. http://dx.doi. org/10.1590/S1413-70542005000100014.

Scarcelli, F. (2015). O mercado de queijo e suas perspectivas. Leite \& Derivados, 152(1), 20-22.

Silva, F. L., \& Fortuna, J. L. (2013). Pesquisa de coliformes em leite tipo C comercializado em supermercados do município de Teixeira de Freitas, BA. Higiene Alimentar, 27(226-227), 116-121.

Silva, G., Silva, A. M. A. D., \& Ferreira, M. P. B. (2012). Processamento de leite. Recife: EDUFRPE.

Silva, N., Junqueira, V. C. A., \& Silveira, N. F. A. (2010). Manual de métodos de análise microbiológica de alimentos e água (4th ed.). São Paulo: Varela.

Tompkin, R. B. (2002). Control of Listeria monocytogenes in the food-processing environment. Journal of Food Protection, 65(4), 709-725. PMid:11952224. 